\title{
Assessing Coronavirus Fear in Indian Population Using the Fear of COVID-19 Scale
}

\section{Dolar Doshi ${ }^{1}$ (D) Parupalli Karunakar ${ }^{2}$. Jagadeeswara Rao Sukhabogi ${ }^{1}$. Jammula Surya Prasanna ${ }^{3}$. Sheshadri Vishnu Mahajan ${ }^{4}$}

Published online: 28 May 2020

(C) Springer Science+Business Media, LLC, part of Springer Nature 2020

\begin{abstract}
The current study aimed to determine the level of fear of COVID-19 among Indian residents using the Fear of COVID-19 Scale (FCV-19S) and compare it with demographic variables. This cross-sectional online survey conducted among the Indian population employed a convenient snowball sampling technique. Age, gender, marital status, educational qualifications, health care worker status and state of residence were the demographic details (six items) collected. The seven-item FCV-19S was used to assess fear regarding COVID-19 on a five-point Likert scale. The mean score for the responses was calculated and compared based on demographic variables. A comparison of low and high levels of fear and a multiple logistic regression analysis of levels of fear with demographic variables were conducted. $p<0.05$ was considered statistically significant. The study population comprised $45.6 \%$ (683) males and 54.4\% (816) females, with approximately $68 \%$ belonging to the age group of $20-40$ years. The overall mean score for the questionnaire was $18.00 \pm 5.68$. A significantly higher number of the study population reported low fear $(54 . \overline{8} \%)$. Only gender $(p=0.08)$ and health care worker status $(p=0.02)$ revealed a significant difference based on the level of fear. Females, married status, lower educational status and being a health care worker displayed significantly higher odds for high level of fear compared to their respective counterparts in this study population. The findings of this study may help to identify the groups most at risk and formulate tailor-made intervention strategies to ensure their optimal health in this time of global crisis.
\end{abstract}

Keywords COVID-19 $\cdot$ Indian $\cdot$ Fear $\cdot$ Fear of COVID-19 scale

On 30 January 2020, Coronavirus Diseases-2019 (COVID-19) was declared a Public Health Emergency of International Concern (World Health Organisation 2020a, b). Owing to the rapid mushrooming of the disease across the globe, on 11 March 2020, the World Health

Dolar Doshi

doshidolar@yahoo.com

Extended author information available on the last page of the article 
Organisation (WHO) announced it as a pandemic with 114 countries affected by then. The highly contagious nature of the disease has lead to mass infection rates and deaths. As of 25 April 2020, globally, the total number of deaths due to COVID-19 as reported by WHO was 187,705 with 2,719,896 confirmed cases of COVID-19 (World Health Organisation 2020c).

Low pathogenicity and high transmissibility are two distinguishing features of this novel coronavirus (Jiang et al. 2020). With adequate information regarding the sources, clinical manifestation and transmission routes (Nemati et al. 2020) of COVID-19, the biggest challenge, as a preventive measure, is the containment of the disease. This has called for behaviour changes at the individual level (wearing masks, social distancing and regular hand hygiene) and lockdown at a country/state level.

Likewise, to check community transmission of the disease, a nationwide lockdown was announced by the Indian Government on 25 March 2020 and was extended until 17 May 2020. This might have caused significant distress in the form of fear, anxiety, agony and confusion among the public. Apart from reducing the transmission rate, considering an individual's fear is a vital aspect for their psychological wellbeing and may also largely influence the manner in which an individual may adhere to preventive measures and thereby determine the clinical outcome of COVID-19.

Recognizing the importance of this, the current study aimed to determine the level of fear of COVID-19 using the Fear of COVID-19 Scale (FCV-19S) and compare it with demographic variables among a convenient sample of the Indian population.

\section{Materials and Method}

Ethical Clearance for this study was obtained from the Institutional Review Board of Panineeya Institute of Dental Sciences, Hyderabad, India.

This cross-sectional online survey employed a convenient snowball sampling technique. Using Google forms, a questionnaire gathering demographic data and fear with respect to COVID-19 was prepared and distributed via Whatapp 1 month post-lockdown (started on 25 April 2020 at 11 am and ended at 26th April 2020 at 11 am). Participation was voluntary and return of completed forms signified informed consent. People with Whatapp, the ability to understand and read English, residing in India and above 18 years of age were included in the study.

Age, gender, marital status, educational qualifications, health care worker status and state of residence were the demographic details (six items) collected. For the state of residence, Indian states were categorized depending on the number of COVID-19 positive cases: Category 1 states had $<500$ cases (Andaman \& Nicobar Island, Arunachal Pradesh, Assam, Bihar, Chandigarh, Chhattisgarh, Goa, Himachal Pradesh, Haryana, Jammu \& Kashmir, Jharkhand, Karnataka, Kerala, Ladakh, Manipur, Meghalaya, Mizoram, Odisha, Puducherry, Punjab, Tripura, Uttarakhand), Category 2 states had $>501$ and $<1500$ cases (Andhra Pradesh, Telangana, Uttar Pradesh, West Bengal) and Category 3 included states with $>1500$ cases (Delhi, Gujarat, Maharashtra, Madhya Pradesh, Rajasthan, Tamil Nadu) as reported by the Ministry of Health and Family Welfare, on 25 April 2020 (Ministry of Health And Family Welfare 2020).

The seven-item Fear of COVID-19 Scale (FCV-19S) developed by Ahorsu et al. (2020) was used to assess fear regarding COVID-19. The responses were recorded on a five-point Likert scale ranging from Strongly Disagree (1) to Strongly Agree (5). The minimum score 
possible for each item is 1 , and the maximum is 5 . A total score is calculated by adding up each item score (ranging from 7 to 35). The higher the score, the greater the fear of COVID-19.

Data was analysed using SPSS software. Descriptive statistics in the form of number and percentage were calculated. Item mean score and overall mean score for the responses were calculated and compared based on demographic variables using t test for two variables and analysis of variance (ANOVA) for three or more variables. Scores were categorized as low and high levels of fear based on the mean, which was taken as a cut-off. The scores less than or equal to the mean were considered as low fear and scores above the mean as high fear. A comparison of low and high levels of fear and a multiple logistic regression analysis of levels of fear with demographic variables were conducted. $p<0.05$ was considered statistically significant.

\section{Results}

A total of 1518 complete responses were obtained, and 1499 responses were considered for final analysis because 19 responses were from outside India. The study population comprised $45.6 \%$ (683) males and $54.4 \%$ (816) females, with approximately $68 \%$ belonging to the age group of 20-40 years. Only a small percentage of the study population were divorced $(0.7 \%)$. Most of the study population were either graduates (44.3\%) or post graduates (48.6\%). The majority of this surveyed population were health care workers $(66.9 \%)$ and over half of them were residents of Category 2 states (51.3\%).

Table 1 Demographic distribution of the study population

\begin{tabular}{lc}
\hline Demographic variable & Respondents \\
& N $(\%)$ \\
\hline Gender & $683(45.6)$ \\
Male & $816(54.4)$ \\
Female & $1022(68.2)$ \\
Age groups & $430(28.7)$ \\
20-40 yrs & $47(3.1)$ \\
$41-60$ yrs & \\
More than 60 yrs & $537(35.8)$ \\
Marital status & $457(30.5)$ \\
Single & $495(33)$ \\
Married & $10(0.7)$ \\
Married with kids & $106(7.1)$ \\
Divorced & $665(44.3)$ \\
Educational status & $728(48.6)$ \\
High school & \\
Graduation & $1003(66.9)$ \\
Post graduation & $496(33.1)$ \\
Health care worker status & \\
Yes & $409(27.3)$ \\
No & $769(51.3)$ \\
State of residence & $321(21.4)$ \\
Category 1 & $1499(100)$ \\
Category 2 & \\
Category 3 & \\
Total &
\end{tabular}


Table 2 Item-wise distribution of responses

\begin{tabular}{|c|c|c|c|c|c|c|}
\hline \multirow{2}{*}{$\begin{array}{l}\text { Item } \\
\text { No. }\end{array}$} & \multirow[t]{2}{*}{ Items } & \multicolumn{5}{|l|}{$\mathrm{N}(\%)$} \\
\hline & & $\begin{array}{l}\text { Strongly } \\
\text { Disagree } \\
\text { (1) }\end{array}$ & $\begin{array}{l}\text { Disagree } \\
(2)\end{array}$ & $\begin{array}{l}\text { Neither } \\
\text { Agree or } \\
\text { Disagree } \\
\text { (3) }\end{array}$ & $\begin{array}{l}\text { Agree } \\
(4)\end{array}$ & $\begin{array}{l}\text { StronglyAgree } \\
\text { (5) }\end{array}$ \\
\hline I1 & $\begin{array}{l}\text { Are you most afraid of coronavirus } \\
\text { disease-19 }\end{array}$ & $\begin{array}{l}117 \\
(7.8)\end{array}$ & $\begin{array}{l}291 \\
(19.4)\end{array}$ & $\begin{array}{l}361 \\
(24.1)\end{array}$ & $\begin{array}{l}582 \\
(38.8)\end{array}$ & $\begin{array}{l}148 \\
(9.9)\end{array}$ \\
\hline I2 & $\begin{array}{l}\text { Does it make you uncomfortable to think } \\
\text { about coronavirus disease- } 19\end{array}$ & $\begin{array}{l}129 \\
(8.6)\end{array}$ & $\begin{array}{l}369 \\
(24.6)\end{array}$ & $\begin{array}{l}292 \\
(19.5)\end{array}$ & $\begin{array}{l}609 \\
(40.6)\end{array}$ & $\begin{array}{l}100 \\
(6.7)\end{array}$ \\
\hline I3 & $\begin{array}{l}\text { Do your hands become clammy when you } \\
\text { think about coronavirus disease- } 19\end{array}$ & $\begin{array}{l}355 \\
(23.7)\end{array}$ & $\begin{array}{l}700 \\
(46.7)\end{array}$ & $\begin{array}{l}218 \\
(14.5)\end{array}$ & $\begin{array}{l}200 \\
(13.4)\end{array}$ & $\begin{array}{c}26 \\
(1.7)\end{array}$ \\
\hline I4 & $\begin{array}{l}\text { Are you afraid of losing your life because } \\
\text { of coronavirus disease- } 19\end{array}$ & $\begin{array}{l}319 \\
(21.3)\end{array}$ & $\begin{array}{l}543 \\
(36.2)\end{array}$ & $\begin{array}{l}278 \\
(18.5)\end{array}$ & $\begin{array}{l}293 \\
(19.6)\end{array}$ & $\begin{array}{c}66 \\
(4.4)\end{array}$ \\
\hline I5 & $\begin{array}{l}\text { When watching news and stories about } \\
\text { coronavirus disease- } 19 \text { on social media, } \\
\text { do you become nervous or anxious }\end{array}$ & $\begin{array}{l}200 \\
(13.3)\end{array}$ & $\begin{array}{l}424 \\
(28.3)\end{array}$ & $\begin{array}{l}279 \\
(18.6)\end{array}$ & $\begin{array}{l}509 \\
(34)\end{array}$ & $\begin{array}{c}87 \\
(5.8)\end{array}$ \\
\hline I6 & $\begin{array}{l}\text { You cannot sleep because you are } \\
\text { worrying about getting coronavirus } \\
\text { disease- } 19\end{array}$ & $\begin{array}{l}539 \\
(36)\end{array}$ & $\begin{array}{l}650 \\
(43.4)\end{array}$ & $\begin{array}{l}179 \\
(11.9)\end{array}$ & $\begin{array}{l}111 \\
(7.4)\end{array}$ & $\begin{array}{c}20 \\
(1.3)\end{array}$ \\
\hline I7 & $\begin{array}{l}\text { Your heart races or palpitates when you } \\
\text { think about coronavirus disease- } 19\end{array}$ & $\begin{array}{l}493 \\
(32.9)\end{array}$ & $\begin{array}{l}622 \\
(41.5)\end{array}$ & $\begin{array}{l}198 \\
(13.2)\end{array}$ & $\begin{array}{l}160 \\
(10.7)\end{array}$ & $\begin{array}{c}26 \\
(1.7)\end{array}$ \\
\hline
\end{tabular}

Tables 1 and 2 display the demographic distribution of the study population and item wise distribution of responses to the questionnaire, respectively. The overall mean score to various items, as represented in Table 3, reveals that for I1 and I2 most of the responses were Neither Agree or Disagree (I1-3.24 $\pm 1.11 ; \mathrm{I} 2-3.12 \pm 1.12$ ). On the other hand, for all other items, the mean responses were mostly Disagree except for I6 (Strongly Agree). A mean item score comparison based on demographic variables showed a significant difference for I1, I2, I4 and I5 items with females and health care workers displaying higher mean scores for all the above items. Age group showed a significant difference only for items I5 and I7, with the younger age group having higher scores. Marital status of the population did not reveal any significant difference in the mean item score for any items. State of residence revealed a significant difference only for I1 and I4 items; conversely, educational status showed a significant difference for all items except I1 and I5.

A significantly higher number of the study population reported low fear (54.8\%). Only gender $(p=0.08)$ and health care worker status $(p=0.02)$ revealed a significant difference based on the level of fear. The overall mean score for the questionnaire was $18.00 \pm 5.68$ with variables such as females, 20-40 year age-group and being a health care worker having significantly higher mean score (Table 4).

Females, married status, lower educational status and being a health care worker displayed significantly higher odds for high level of fear compared to their respective counterparts in this study population (Table 5).

\section{Discussion}

As a first step to combat any infectious disease pandemic in nature, it is important to assess the knowledge and awareness regarding the disease which has been reported by various studies in 
Table 3 Item wise mean score comparison based on demographic variables

\begin{tabular}{|c|c|c|c|c|c|c|c|}
\hline Variable & I1 & $\mathrm{I} 2$ & $\mathrm{I} 3$ & I4 & I5 & I6 & $\mathrm{I} 7$ \\
\hline \multicolumn{8}{|l|}{ Gender } \\
\hline Male & $3.14+1.18$ & $3.04+1.18$ & $2.23+1.05$ & $2.44+1.16$ & $2.77+1.18$ & $1.93+0.98$ & $2.04+1.05$ \\
\hline Female & $3.32 \pm 1.04$ & $3.19 \pm 1.06$ & $2.23 \pm 0.98$ & $2.44 \pm 1.15$ & $3.02 \mp 1.16$ & $1.96 \pm 0.91$ & $2.10 \pm 0.99$ \\
\hline$p$ value & $0.00 \overline{6^{*}}$ & $0.01 \%$ & $0.65^{-}$ & $0.05^{*}$ & $0.000 \overline{1} *$ & $0.17^{-}$ & $0.07^{-}$ \\
\hline \multicolumn{8}{|l|}{ Age groups } \\
\hline $20-40 \mathrm{yrs}$ & $3.26+1.09$ & $3.12+1.11$ & $2.26+1.00$ & $2.53+1.18$ & $2.99+1.18$ & $1.98+0.95$ & $2.10+1.02$ \\
\hline $41-60$ yrs & $3.20 \mp 1.14$ & $3.15 \mp 1.12$ & $2.16 \mp 1.01$ & $2.44 \mp 1.09$ & $2.76 \mp 1.15$ & $1.88 \mp 0.92$ & $2.03 \mp 1.03$ \\
\hline $\begin{array}{l}\text { More than } \\
60 \text { yrs }\end{array}$ & $3.11 \pm 1.22$ & $2.96 \pm 1.22$ & $2.15 \pm 1.12$ & $2.26 \pm 1.07$ & $2.49 \pm 1.18$ & $1.83 \pm 0.89$ & $1.79 \pm 0.88$ \\
\hline$p$ value & 0.50 & 0.49 & 0.09 & 0.24 & $0.0001 *$ & 0.10 & $0.05^{*}$ \\
\hline \multicolumn{8}{|l|}{ Marital status } \\
\hline Single & $3.19 \pm 1.07$ & $2.99 \pm 1.09$ & $2.19 \pm 0.97$ & $2.56 \pm 1.23$ & $2.91 \pm 1.21$ & $1.85 \pm 0.89$ & $2.00 \pm 0.98$ \\
\hline Married & $3.21 \mp 1.18$ & $3.20 \mp 1.19$ & $2.28 \overline{+} 1.08$ & $2.46 \overline{+} 1.09$ & $2.88 \mp 1.16$ & $1.96 \overline{+} 0.98$ & $2.08+1.03$ \\
\hline $\begin{array}{l}\text { Married with } \\
\text { kids }\end{array}$ & $3.30 \pm 1.09$ & $3.19 \pm 1.06$ & $2.22 \pm 0.99$ & $2.45 \pm 1.13$ & $2.91 \pm 1.15$ & $2.03 \pm 0.95$ & $2.14 \pm 1.05$ \\
\hline Divorced & $3.60 \pm 1.26$ & $3.50 \pm 1.18$ & $2.40 \pm 0.97$ & $2.90 \pm 1.29$ & $3.20 \pm 1.14$ & $2.20 \pm 1.32$ & $1.80 \pm 0.92$ \\
\hline$p$ value & 0.41 & $0.55^{-}$ & $0.74^{-}$ & $0.47^{-}$ & $0.62^{-}$ & $0.33^{-}$ & $0.43^{-}$ \\
\hline \multicolumn{8}{|c|}{ Educational status } \\
\hline High school & $3.25 \pm 1.09$ & $2.99 \pm 1.13$ & $2.53 \pm 1.20$ & $2.79 \pm 1.28$ & $2.87+1.30$ & $2.15+1.04$ & $2.41+1.18$ \\
\hline Graduation & $3.23 \mp 1.07$ & $3.06 \mp 1.08$ & $2.26 \mp 0.98$ & $2.55 \mp 1.16$ & $2.91 \mp 1.17$ & $1.98 \mp 0.93$ & $2.08 \mp 0.99$ \\
\hline $\begin{array}{l}\text { Post } \\
\text { graduation }\end{array}$ & $3.24 \pm 1.15$ & $3.20 \pm 1.15$ & $2.16 \pm 1.00$ & $2.40 \pm 1.12$ & $2.91 \pm 1.16$ & $1.89 \pm 0.94$ & $2.01 \pm 1.02$ \\
\hline$p$ value & 0.87 & $0.01 *$ & $0.002 *$ & $0.003 *$ & 0.95 & $0.009^{*}$ & $0.001 *$ \\
\hline \multicolumn{8}{|c|}{ Health care worker } \\
\hline Yes & $3.28+1.11$ & $3.17+1.11$ & $2.24+1.02$ & $2.54+1.16$ & $2.97+1.19$ & $1.95+0.93$ & $2.06+1.02$ \\
\hline No & $3.14 \mp 1.12$ & $3.03 \mp 1.12$ & $2.21 \mp 0.99$ & $2.40 \mp 1.13$ & $2.78 \mp 1.14$ & $1.95 \mp 0.97$ & $2.09 \mp 1.02$ \\
\hline$p$ value & $0.01^{-}$ & $0.02^{*}$ & 0.62 & $0.02 *$ & $0.00^{*}$ & 0.72 & 0.59 \\
\hline \multicolumn{8}{|c|}{ State of residence } \\
\hline Category 1 & $3.28+1.10$ & $3.15+1.13$ & $2.23+1.00$ & $2.63+1.15$ & $3.00+1.16$ & $1.98+0.92$ & $2.09+1.00$ \\
\hline Category 2 & $3.28 \mp 1.10$ & $3.16 \mp 1.09$ & $2.26 \mp 1.02$ & $2.45 \mp 1.15$ & $2.85 \mp 1.18$ & $1.93 \mp 0.96$ & $2.08 \mp 1.03$ \\
\hline Category 3 & $3.08 \mp 1.15$ & $3.00 \mp 1.17$ & $2.15 \pm 1.00$ & $2.43 \pm 1.15$ & $2.93 \mp 1.18$ & $1.96 \mp 0.95$ & $2.02 \pm 1.02$ \\
\hline$p$ value & $0.02^{*}$ & 0.14 & 0.25 & $0.01 *$ & 0.10 & $0.37^{-}$ & 0.45 \\
\hline Total & $3.24+1.11$ & $3.12+1.12$ & $2.23+1.01$ & $2.50+1.15$ & $2.91+1.17$ & $1.95+0.95$ & $2.07+1.02$ \\
\hline
\end{tabular}

$* p<0.05$ statistically significant

different populations (Ahmed et al. 2020; Geldsetzer 2020; Modi et al. 2020; Nemati et al. 2020; Roy et al. 2020; Zhong et al. 2020; Zhou et al. 2020). At the same time, the impact of a pandemic on psychological health is an important factor in determining the mental well-being of individuals. Our study highlights the initial psychological reponses in the form of fear towards the life threatening pandemic of COVID-19 1 month post-lockdown. This period signifies the waning of the novelty effect of lockdown and surfacing of real-time difficulties which may be due to restricted mobility and might manifest as panic and fear towards the disease.

The psychological determinant of health has always been underplayed, but in situations such as COVID-19, it emerges as a significant factor; hence, we aimed to understand the effect of fear among the Indian population. The Fear of COVID-19 Scale (FCV-19S) has been utilized in this study as it has proven to have robust psychometric properties, with comparability among both genders and across all age groups to assess and allay fears in individuals (Ahorsu et al. 2020; Pakpour and Griffiths 2020).

In this study, due to logistic concerns, a convenient snowball sampling method was applied, which could also be the reason for a few samples (19) being represented from outside India 
Table 4 Levels of fear and mean score comparison based on variables

\begin{tabular}{|c|c|c|c|c|c|}
\hline \multirow[t]{2}{*}{ Variable } & \multicolumn{2}{|l|}{$\mathrm{N}(\%)$} & \multirow[t]{2}{*}{$p$ value } & \multirow[t]{2}{*}{ Mean \pm SD } & \multirow[t]{2}{*}{$p$ value } \\
\hline & Low & High & & & \\
\hline \multicolumn{6}{|l|}{ Gender } \\
\hline Male & $400(58.6)$ & $283(41.4)$ & \multirow{2}{*}{$0.008^{*}$} & $17.57 \pm 5.87$ & \multirow[t]{2}{*}{$0.007 *$} \\
\hline Female & $422(51.7)$ & $394(48.3)$ & & $18.36 \mp 5.50$ & \\
\hline \multicolumn{6}{|l|}{ Age groups } \\
\hline $20-40 \mathrm{yrs}$ & $546(53.4)$ & $476(46.6)$ & \multirow[t]{3}{*}{0.27} & $18.23+5.66$ & \multirow[t]{3}{*}{$0.03^{*}$} \\
\hline $41-60$ yrs & $249(57.9)$ & $181(42.1)$ & & $17.62 \mp 5.69$ & \\
\hline More than $60 \mathrm{yrs}$ & $27(57.4)$ & $20(42.6)$ & & $16.57 \pm 5.63$ & \\
\hline \multicolumn{6}{|l|}{ Marital status } \\
\hline Single & $296(55.1)$ & $241(44.9)$ & \multirow[t]{4}{*}{0.90} & $17.70 \pm 5.65$ & \multirow[t]{4}{*}{0.35} \\
\hline Married & $245(53.6)$ & $212(46.4)$ & & $18.07 \mp 5.72$ & \\
\hline Married with kids & $276(55.8)$ & $219(44.2)$ & & $18.24 \mp 5.66$ & \\
\hline Divorced & $5(50)$ & $5(50)$ & & $19.60 \mp 6.57$ & \\
\hline \multicolumn{6}{|l|}{ Educational status } \\
\hline High school & $51(48.1)$ & $55(51.9)$ & \multirow[t]{3}{*}{0.15} & $18.98+6.69$ & \multirow[t]{3}{*}{0.12} \\
\hline Graduation & $356(53.5)$ & $309(46.5)$ & & $18.07 \mp 5.46$ & \\
\hline Post graduation & $415(57)$ & $313(43)$ & & $17.80 \mp 5.71$ & \\
\hline \multicolumn{6}{|l|}{ Health care worker } \\
\hline Yes & $529(52.7)$ & $474(47.3)$ & \multirow[t]{2}{*}{$0.02 *$} & $18.21+5.69$ & \multirow[t]{2}{*}{$0.04 *$} \\
\hline No & $293(59.1)$ & $203(40.9)$ & & $17.58 \mp 5.64$ & \\
\hline \multicolumn{6}{|l|}{ State of residence } \\
\hline Category 1 & $217(53.1)$ & $192(46.9)$ & \multirow[t]{3}{*}{0.51} & $18.36+5.69$ & \multirow[t]{4}{*}{0.16} \\
\hline Category 2 & $421(54.8)$ & $348(45.2)$ & & $17.99 \mp 5.63$ & \\
\hline Category 3 & $184(57.3)$ & $137(42.7)$ & & $17.57 \mp 5.79$ & \\
\hline Total & $822(54.8)$ & $677(45.2)$ & 0.001 & $18.00 \mp 5.68$ & \\
\hline
\end{tabular}

$* p<0.05$ statistically significant

that were therefore excluded from the final analysis. With India being a large country, and the number of COVID-19 cases varying greatly across the nation, we attempted to categorize the states based on the number of positive cases and mark its effect on fear. Nevertheless, it was observed that the residents of states with fewer cases (Category 1) reported higher fear levels, which could be because of the more stringent measures followed by them to prevent the further spread of the virus.

An important aspect of our study was to identify high-risk populations for early psychological interventions. In our study, demographic variables such as females, married people, lower educational status and health care workers emerged to be at higher risk of having greater fear towards COVID-19.

In the literature (Lim 2018; Wang et al. 2020), it has been found that females are more prone to stress, depression and anxiety. Likewise, in this study, females had 1.29 times significantly higher odds to fear COVID-19 compared with their male counterparts. Higher odds based on marital status were seen for all the sub-groups but was significant only for the married group (Odds ratio $1.45 ; p=0.01$ ). This could be attributed to the increased sense of responsibility and added concern towards their loved ones.

Lower educational status might significantly influence the manner in which an individual comprehends the infection. The mere guidelines of a stringent hygiene code of behaviour could enhance fear among them. Therefore, an effort has to be made to impart information in local vernacular languages and to use a pictorial and schematic approach along with audio 
Table 5 Multiple logistic regression analysis of levels of fear with demographic profile

\begin{tabular}{|c|c|c|c|c|c|c|}
\hline \multirow[t]{2}{*}{ Demographic variables } & \multirow[t]{2}{*}{$\mathrm{N}(\%)$} & \multirow{2}{*}{$\begin{array}{l}\text { High fear } \\
\mathrm{N}(\%)\end{array}$} & \multirow[t]{2}{*}{ OR } & \multicolumn{2}{|c|}{$95 \%$ OR } & \multirow[t]{2}{*}{$p$ value } \\
\hline & & & & Lower & Upper & \\
\hline \multicolumn{7}{|l|}{ Gender } \\
\hline Male & $683(45.6)$ & $283(41.4)$ & Ref. & & & \\
\hline Female & $816(54.4)$ & $394(48.2)$ & 1.29 & 1.04 & 1.60 & $0.02 *$ \\
\hline \multicolumn{7}{|l|}{ Age groups } \\
\hline $20-40 \mathrm{yrs}$ & $1022(68.2)$ & $476(46.6)$ & Ref. & & & \\
\hline $41-60$ yrs & $430(28.7)$ & $181(42.1)$ & 0.83 & 0.64 & 1.08 & 0.17 \\
\hline More than $60 \mathrm{yrs}$ & $47(3.1)$ & $20(42.6)$ & 0.91 & 0.49 & 1.69 & 0.76 \\
\hline \multicolumn{7}{|l|}{ Marital status } \\
\hline Single & $537(35.8)$ & $241(44.9)$ & Ref. & & & \\
\hline Married & $457(30.5)$ & $212(46.4)$ & 1.45 & 1.07 & 1.95 & $0.01 *$ \\
\hline Married with kids & $495(33)$ & $219(44.2)$ & 1.27 & 0.95 & 1.70 & 0.10 \\
\hline Divorced & $10(0.7)$ & $5(50)$ & 1.77 & 0.49 & 6.34 & 0.38 \\
\hline \multicolumn{7}{|l|}{ Educational status } \\
\hline High school & $106(7.1)$ & 55 (51.9) & 1.56 & 1.02 & 2.38 & $0.04 *$ \\
\hline Graduation & $665(44.3)$ & $309(46.5)$ & 1.24 & 0.99 & 1.56 & 0.06 \\
\hline Post graduation & $728(48.6)$ & $313(43)$ & Ref. & & & \\
\hline \multicolumn{7}{|l|}{ Health care worker } \\
\hline Yes & 1003 (66.9) & $474(47.3)$ & 1.37 & 1.09 & 1.72 & $0.00^{*}$ \\
\hline No & $496(33.1)$ & $203(40.9)$ & Ref. & & & \\
\hline \multicolumn{7}{|l|}{ State of residence } \\
\hline Category 1 & 409 (27.3) & $192(46.9)$ & 1.19 & 0.88 & 1.61 & 0.26 \\
\hline Category 2 & $769(51.3)$ & $348(45.2)$ & 1.17 & 0.89 & 1.53 & 0.26 \\
\hline Category 3 & $321(21.4)$ & $137(42.7)$ & Ref. & & & \\
\hline
\end{tabular}

$p<0.05$ statistically significant

messages to support such a group. This strategy has been very well adapted by the Government of India by providing easy access to these materials online (regional languages), diagrammatic representations at public places in the form of posters and regular circulation of audio messages through mass media (Ministry of Health And Family Welfare 2020).

A surprising finding of our study is the significantly heightened fear of this infection among health care workers compared to their counterparts (Odds ratio 1.37). This may be due to their direct close interaction with COVID-19 positive patients, a better understanding of the disease development, progression and consequence in the form of fatality associated with the contagion.

However, when the overall mean score of this population was considered it was $18.00 \pm$ 5.68, which illustrates the positive frame of mind of the people who help fight this illness. People should be encouraged to rely on authentic sources of information, adopt health promoting behaviors, support each other and seek timely professional help through various online platforms (Lin 2020).

The convenience sampling methodology along with the Smartphone based application and English language literacy may prevent the generalization of the survey and present as shortcomings of the study. The self-report nature of the questionnaire may exhibit social desirability bias. Evaluation of a subjective factor such as fear objectively itself presents as a limitation of the study. The cross-sectional design of the study may prevent establishing a cause-effect relationship, emphasizing the need for a prospective longitudinal study. 
Nevertheless, a large sample size and use of a standardized questionnaire displays the strengths of this study.

\section{Conclusion}

This study portrays an urgent need to conduct a nationwide epidemiological study to determine the level of fear as well as other associated issues concerning mental health in relation to COVID-19. The findings of this study may help to identify the groups most at risk and formulate tailor-made intervention strategies to ensure their optimal health in this time of global crisis.

\section{Compliance with Ethical Standards}

Conflict of Interest The authors declare that they have no conflict of interest.

Ethical approval Ethical approval for this study was obtained from the Institutional Review Board of Panineeya Institute of Dental Sciences, Hyderabad, India.

Statement of informed consent Participation was voluntary and return of completed forms signified informed consent.

\section{References}

Ahmed, M. A., Jouhar, R., Ahmed, N., Adnan, S., Aftab, M., Zafar, M. S., \& Khurshid, Z. (2020) Fear and practice modifications among dentists to combat novel coronavirus disease (COVID-19) outbreak. International Journal of Environmental Research and Public Health 17, 2821.

Ahorsu, D. K., Lin, C. Y., Imani, V., Saffari, M., Griffiths, M. D., \& Pakpour, A. H. (2020). The fear of COVID19 scale: Development and initial validation. International Journal of Mental Health and Addiction. 1-9. https://doi.org/10.1007/s11469-020-00270-8.

Geldsetzer, P. (2020). Knowledge and perceptions of COVID-19 among the general public in the United States and the United Kingdom: A cross-sectional online survey. Annals of Internal Medicine. https://oi. org/10.7326/M20-0912.

Jiang, S., Shi, Z., Shu, Y., Song, J., Gao, G. F., Tan, W., \& Guo, D. (2020). A distinct nameis needed for the new coronavirus. Lancet, 395(10228), 949. https://doi.org/10.1016/S0140-6736(20)30419-0.

Lim, G. Y. (2018). Prevalence of depression in the community from 30 countries between 1994 and 2014. Scientific Reports, 8, 2861.

Lin, C. Y. (2020). Social reaction toward the 2019 novel coronavirus (COVID-19). Social Health And Behavior, $3(1), 1$.

Ministry of Health And Family Welfare. (2020). Government of India. https://www.mohfw.gov.in/. Accessed on 25 April 2020.

Modi, P. D., Nair, G., Uppe, A., Modi, J., Tuppekar, B., Gharpure, A. S., \& Langade, D. (2020). COVID-19 awareness among healthcare students and professionals in Mumbai metropolitan region: A questionnairebased survey. Cureus, 12(4), e7514. https://doi.org/10.7759/cureus.7514.

Nemati, M., Ebrahimi, B., \& Nemati, F. (2020). Assessment of Iranian nurses' knowledge and anxiety toward COVID-19 during the current outbreak in Iran. Archives of Clinical Infectious Diseases, 15(COVID-19), e102848.

Pakpour, A.H., \& Griffiths, M.D. (2020). The fear of COVID-19 And its role in preventive behaviors. Journal Of Concurrent Disorders, 2(1), 58-63.

Roy, D., Tripathy, S., Kar, S.K., Sharma, N., \& Kaushal, V. (2020). Study of knowledge, attitude, anxiety \& perceived mental healthcare need in Indian population during COVID-19 pandemic. Asian Journal of Psychiatry, 51, 102083. 
Wang, C., Pan, R., Wan, X., Tan, Y., Xu, L., Ho, C. S., \& Ho, R. C. (2020). Immediate psychological responses and associated factors during the initial stage of the 2019 coronavirus disease (COVID-19) epidemic among the general population in China. International Journal of Environmental Research and Public Health, 17, 1729.

World Health Organisation (2020a). Coronavirus disease (COVID-2019): Situation report-46 https:/www.who. int/docs/default-source/coronaviruse/situation-reports/20200306-sitrep-46-covid19.pdf?sfvrsn=96b04adf_4. Accessed on 25 April 2020.

World Health Organisation (2020b). Rolling Updates on Corona Virus COVID -10. https://www.who. int/emergencies/diseases/novel-coronavirus-2019/events-as-they-happen. Accessed on 25 April 2020.

World Health Organisation (2020c). Coronavirus disease (COVID-2019): Situation report -46 https:/www.who. int/docs/default-source/coronaviruse/situation-reports/20200425-sitrep-96-covid-19.pdf?sfvrsn=a33836 bb_4. Accessed on 25 April 2020.

Zhong, B. L., Luo, W., Li, H. M., Zhang, Q. Q., Liu, X. G., Li, W. T., \& Li, Y. (2020). Knowledge, attitudes, and practices towards COVID-19 among Chinese residents during the rapid rise period of the COVID-19 outbreak: A quick online cross-sectional survey. International Journal of Biological Sciences, 16(10), 1745-1752.

Zhou, M., Tang, F., Wang, Y., Nie, H., Zhang, L., You, G., \& Zhang, M. (2020). Knowledge, attitude and practice regarding COVID-19 among health care workers in Henan, China. Journal of Hospital Infection. https://doi.org/10.1016/j.jhin.2020.04.012.

Publisher's Note Springer Nature remains neutral with regard to jurisdictional claims in published maps and institutional affiliations.

\section{Affiliations}

\section{Dolar Doshi ${ }^{1} \cdot$ Parupalli Karunakar ${ }^{2}$ • Jagadeeswara Rao Sukhabogi ${ }^{1} \cdot$ Jammula Surya Prasanna $^{3}$ - Sheshadri Vishnu Mahajan ${ }^{4}$}

1 Department of Public Health Dentistry, Government Dental College and Hospital, Room No. 311, Hyderabad, India

2 Department of Conservative Dentistry and Endodontics, Panineeya Institute of Dental Sciences and Hospital, Hyderabad, India

3 Department of Periodontics, Panineeya Institute of Dental Sciences and Hospital, Hyderabad, India

4 Department of Ophthalmology, BMC, Hyderabad, India 